Memories of Sherrington

\section{C.G. Phillips}

Sherrington: His Life and Thought. By J. C. Eccles and W. C. Gibson. Pp. 269. (Springer International: Berlin, Heidelberg and New York, 1979.) DM34.

SHERRINGTON died in 1952. Within ten years a young collaborator of Ragnar Granit's was confessing that his generation knew nothing about him. Granit's answer was that many of the conceptual foundations of their research were created in Sherrington's mind. His oevre is remarkable for its sheer coherence. Discoveries and rediscoveries fall into place in an almost continuous narrative, as can be seen in Denny-Brown's Selected Writings of Sir Charles Sherrington, now reprinted by Oxford University Press for the Guarantors of the journal Brain. These, together with The Integrative Action of the Nervous System (1906) and the last chapter of Reflex Activity of the Spinal Cord (reissued recently by Oxford University Press on D.P.C. Lloyd's initiative), are all readily available to anyone who wishes to know and value Sherrington's achievement. $\mathrm{He}$ was evidently concerned to leave his scientific testament in good order. Many will wonder at his highly individual literary style, seemingly so contorted in places and contrasting so strongly with the plain English in which he wrote the letters and reminiscences now published in Eccles' and Gibson's book. One has to remember thai he was striving to express ideas which were not yet familiar to his readers. R.S. Creed in his memoir explains that Sherrington's first care was to escape ambiguity and to be concise, rather than to be immediately intelligible. The contortions were not casualties of confused thinking, but the result of deliberate rewriting, often delayed by the search for some crucial word. On these foundations neuroscientists are still building, usually as unconsciously as Granit's pupil. Though modest in manner, Sherrington was not quite without vanity: Denny-Brown has told how he "shyly" produced Hamburger's comment (which prefaces Selected Writings) that anyone who had witnessed his demonstration of reciprocal inhibition in a monkey at the Fourth International Congress of Physiologists in 1898 "a enrichi sa connaissance pour toujours". But in his preface to the re-issue of the Integrative Action (1947: extracts reprinted by Eccles and Gibson) he referred to it as "my rather elderly book". To J.F. Fulton he wrote (when he had just retired, in his late seventies): "Thank you for mentioning again that the old Integrative Action still floats. I know how generously you regard it, and am very grateful. But looked at rigidly I cannot but recognise that it has "had its day". Its best future is for what lives of it to be incorporated unobtrusively - into what is written with similar scope, now and after, for a time". At about the same period, in his review in Nature of Romón y Cajal's autobiography, he quoted the "wistful" passage in which his old friend, whose structural work on the neurone had always complemented his own physiological work, accepted that "the facts associated at first with the name of a particular man end by being anonymous, lost for ever in the ocean of Universal Science. The monograph impregnated with individual human quality becomes incorporated,stripped of sentiments, in the abstract doctrine of the general treatise. To the hot sun of actuality will succeed the cold beams of the history of learning". Sherrington's comment: "We may express this in short by saying that, as Aristotle thought of the soul, a scientific writing has no personal immortality'. Yet active scientists do sometimes go to the writings of their forebears for inspiration - a creative act of ancestor-worship.

C.E.R. Sherrington, in his Memories now published by Eccles and Gibson, wrote that his father was averse to the idea of any "extensive biography". Sherrington's pupils have respected this wish. In formal memoirs, written at the time of his death, they have recorded the facts of his career and the people who helped and influenced him. Of these memoirs, that by E.G.T. Liddell, in the Royal Society's series, is the acknowledged masterpiece. Liddell's homage took the form of a remarkable book, Discovery of Reflexes, in which, with the insights of a neuroscientist as well as those of a scholar who reads seventeenth-century Latin as well as French and German, he painted a splendid landscape of knowledge and ideas about the nervous system at the time when Sherrington began to publish in 1884 . This sets in relief the veritably Harveian revolution which Sherrington brought about. Ragnar Granit's Charles Scott Sherrington: An Appraisal tells of the modern experimental exploitation of Sherrington's seminal discoveries and concepts: the synapse; central inhibition as an active process; convergence and interaction of excitatory and inhibitory synaptic inputs at the neuronal membrane; receptor organs in muscle and their reflex actions, as proof of their continuing vitality. Eccles and Gibson have also respected Sherrington's wish, though a sentence at the beginning of their Preface (not to mention "the definitive Sherrington biography" proclaimed by the publisher's dust-jacket blurb) might have alarmed him. "More and more, students of history are calling for creative writing on the whole man, particularly when he is a genius. Those interested in the genesis of ideas want to know the settings for discoveries and the relevant circumstances which ushered in new truths and insights". "Creative writing on the whole man" suggests imaginative reconstruction of feelings and motives and of intimate personal relationships. His visits to Eastbourne left Liddell in no doubt about Sherrington's feelings in his very old age. "Hardly ever, he felt, can a biographer discern and interpret the inner thoughts which have moved the mind of another man years before. The mind made the man, and its achievements alone are worth recording". But Eccles and Gibson's wholly delightful book is not that sort of biography. In the first place, getting on for one-third of the words are those of Sherrington himself, a charming anthology of writings relating largely to life outside the laboratory. In the second, the wellknown landmarks of his career are freshly illuminated by quotation from a large collection of letters, which, together with other Sherringtoniana, are housed in Professor Gibson's Department of the History of Science and Medicine in the University of British Columbia. Thirdly, both authors worked in Sherrington's laboratory at Oxford, and now add their personal witness to that of the others who shared in the action during his last years, when, in his seventies, he had steered his reflex experiments away from their significance as items of adaptive behaviour and into the neuronal basis of their physiological production and execution, and had brought them to their zenith of technical refinement and quantitative precision.

The Preface says that the book will concentrate on themes that have been "but lightly touched on" by previous writers. One only of its promises is not performed: one finds nothing about any analysis by Sherrington of the lack of productivity of British medical science at the end of the nineteenth century. For readers whose first love is to do experiments, Eccles' story of his exciting years with Sherrington in the 1920 s and 1930 s will be the highlight of the book. They were counting the musclefibres in the motor units and estimating their average contractile force. (The cautionary tale of the "muscle angle" comes in here). The motor nerves had to be emptied of afferent axons by antecedent dorsal root ganglionectomy. Sherrington was not only skilled in this delicate operation, but was also responsible for the perfectly circular and uncrinkled appearance of the myelinated motor axons in transverse sections; he dehydrated the splinted nerves overnight in his bathroom at home, and spent many happy hours in teasing nerves in order to prove the branching of motor axons. They noted the two peaks in the axon diameter spectrum, but inexplicably, in view of their awareness of the motor innervation of muscle spindles and of Sherrington's discussion of its possible significance in his Linacre Lecture 
in 1924, failed to suggest that the smallercalibre group was fusimotor. Then came the long series of experiments on the interaction of excitatory and inhibitory reflex imputs, testing Sherrington's already-published theories and leading up to their culminating statement in the final chapter of Reflex Activity of the Spinal Cord. The atmosphere of the laboratory comes to life as we learn how they recited Keats and Bridges during the routine preparations, how Sherrington spoke of such things as his belief that Verocchio's studio was like a modern research laboratory, and how, on those two strenuous days each week, they missed lunch but went into the town for an enormous afternoon tea before the final recording session.

Eccles' involvement in the mind-brain problem is well known, most recently from his book with K.R. Popper (The Self and Its Brain; Springer: Berlin; for review, see Nature, 272, 770; 1978), and his Gifford Lectures have also been published by Springer this year as The Human Mystery. Sherrington thought deeply about the problem in his last years. In 1922, in his Presidential Address to the British Association (reprinted in an Appendix as The Times' report), he spoke in evolutionary terms of the "twilit emergence of mind from non-mind, which is repeated in the individual life-history". His Rede Lecture, The Brain and its Mechanism (1933) was "eagerly read" in the laboratory "as giving some glimpse of the philosophical thinking he had been developing unbeknown to us". In his Gifford Lectures, Man on his Nature, first published in 1940, and about which, also, he was "secretive" (or dismissive: to Fulton - "I fear they are not interesting") he developed these themes in a biological epic of Homeric stature, its whole conception and wealth of illustration the product, as Eccles well says, of one of the most cultivated minds of the modern world. The Lectures were on Natural (as distinct from Revealed) Religion, and the audience, mainly of clergymen, can have received little comfort. Supernatural explanations of biological phenomena heredity, ontogeny, adaptation for survival - had been replaced by natural explanations or shown to be replaceable in principle. Animate nature is amoral and much of it can only be valued by moral beings as loathsome. Yet, though mindless, its products adapt to pressures which threaten survival in ways which seem purposeful. Then comes the gradual emergence of "recognisable mind", linked with the appearance of bigger and more complex brains, and conferring increasing domination of the environment and of other species. Eventually there appear aesthetic and moral qualities which give hope that altruism will supplant predatory behaviour. "It may likely mean a human future led by women more eminently than by men". Yet neurone and synapse seem everywhere the same; and, in spite of the essential unity of bodily and mental life, analysis finds two modes of activity, mind and energy - irreducibly. Confronted with this twentieth-century epic, different readers will respond differently. Eccles' response, as shown in the passages he has chosen and in his commentaries, follows the lines of his well-known books, but differs for example from. Granit's (we may think) equally valid one. One can agree that Sherrington "embraces as equals all the values", but be puzzled by the statement (page 156) that he "even exalts altruism

Sorry, for copyright
reasons some images
on this page may not
be available online

above truth". One hopes that readers will be encouraged to go to the source. Schrodinger wrote: "I cannot convey the grandeur of Sherrington's immortal book by quoting sentences; one has to read it oneself"'.

Though deadlocked about how mind and energy interact in the brain, and unwilling to propose any hypothesis, Sherrington had written (in the Rede Lecture) "I am not a defeatist, for I would urge active pursuit of the enquiry", though "it seems to me, speaking in all humility, that from time to time the biologist has to make plain how far or near he is from the answer". If "man, the best among us", finds out "how the brain does its thinking", he "will certainly try to improve its ways of doing so ... We need not be prophets to foresee that then will come the long-told speedy extinction of man. The planet will then be re-liberated, free for the next era of animal domination". Today it seems that the same danger could come from psychotropic substances discovered by chemists, whose control of thought and behaviour might bring extinction before neuroscientists have had time to discover "how the brain does its thinking".

Professor Gibson's quotations from his collection of letters illuminate the whole range of Sherrington's activities. As a professor, he never had a secretary, but wrote his many letters by hand and kept his files himself, with help from his wife. He could rely on an extraordinary memory. His letter of 1947, describing how his pioneering use of diphtheria antitoxin saved the life of his eight-year-old nephew in 1893 or 1894 , is reproduced in facsimile. Although genial he could be firm when necessary - as when the Dean at Liverpool, an anatomist, tried to cut physiology by half and pathology by a third to gain more time for anatomy. He helped many people, notably Harvey Cushing, Wilder Penfield, Hugh Cairns and Howard Florey, in their careers. Private donors gave hime money for research. In thanking the British Medical Association for financial support, he drew public attention to the $£ 4,000$ per annum which in 1907 was all the Government gave to the Royal Society to support research in all fields in the whole of the British Empire. "The sum is about the same in amount as - sad to say - the average yearly takings of a publichouse in a poor quarter of this city". $\mathrm{He}$ spent much trouble on public education and in service on committees - writing articles for the Encyclopaedia Britannica, six chapters for a manual of school hygiene, reports on health in schools, on the importance of longer hours of sleep in public schools, on tests for sight and colour blindness, and even on the infectivity of oysters. Partly to study industrial fatigue he worked during the long vacation of 1915 (he was 58) in a munitions factory. No-one knew who he was, and the foreman offered to write him a good testimonial. Asked by Alan Gregg of the Rockefeller Foundation about the function of modern Oxford, he replied that it could no longer rely on its centuries-old skills in teaching what is known, but "must learn how to teach the best attitude to what is not yet known. This also may take centuries to acquire but we cannot escape this new challenge, nor do we want to".

Gibson has a fine chapter on Sherrington the Poet, illustrated by several sonnets and extracts from longer pieces. His work was taken seriously by Hardy, Edmund Gosse and Walter de la Mare. An appendix reprints his undergraduate essay on Longfellow. There is a good deal of correspondence about his lifelong collection of incunabula - another interest about which he was ordinarily extremely reticent. His gifts to the British Museum marked him as its "best benefactor in modern times". Then there is his hilarious account of Christmas at Grindelwald in 1887. And so on. Having read it all you will want to browse frequently.

C.G. Phillips is Dr Lee's Professor of Anatomy at $O x$ ford and Editor of Brain. 